Reprod. Nutr. Dévelop., 1982, 22 (3), 485-493.

\title{
Influence of season on mean plasma levels of prolactin, placental lactogen hormone and luteinizing hormone during the second half of gestation in the ewe
}

\author{
M. J. BOSC, J. DJIANE $\left({ }^{*}\right)$, P. DURAND, J. PELLETIER, J. P. RAVAULT $(* *)$ \\ Station de Physiologie de la Reproduction, I.N.R.A. \\ Nouzilly 37380 Monnaie, France \\ $\left({ }^{*}\right)$ Station de Physiologie de la Lactation, I.N.R.A. \\ 78350 Jouy-en-Josas, France \\ (**) Laboratoire de Physiologie comparée \\ Faculté des Sciences, 37200 Tours, France
}

Summary. Mean plasma levels of prolactin (PRL), placental lactogen (OCS) and luteinizing hormone (LH) have been studied in pregnant ewes at different times of the year from approximately day 60 of gestation until parturition. Three groups were constituted and inseminated at different times: September, group I; November, group II ; March, group III. Blood samples were collected on two consecutive days approximately every 10 days. The results indicate that plasma PRL levels are influenced by the season. In group I, PRL concentrations were 3 and 2 times less than those of group III during the third and fifth months of gestation. OCS levels, strongly dependent on the stage of gestation, were not significantly affected by the season. LH concentrations remained low in all three groups throughout the studied period of gestation.

\section{Introduction}

In sheep, seasonal variation in the daylength modulates hypophyseal gonadotropic activity and thus the secretion of follicle-stimulating hormone, luteinizing hormone (LH) and prolactin (PRL) in the ram (Pelletier and Ortavant, 1970 ; Ravault, 1976 ; Ravault et al., 1980) and the ewe (Thimonier and Mauléon, 1969 ; Thimonier et al., 1978). The interactions between daylength and hormonal secretions have not been studied in the pregnant ewe. In late gestation, blood PRL levels increase dramatically (Kann and Denamur, 1974) and the photoperiod could well influence its secretion, as shown during early gestation (Rhind et al., 1978). However, in the ewe, most blood lactogenic activity is due to the secretion of a placental lactogenic hormone (OCS) (Kelly et al., 1974; Djiane and Kann, 1975). The method of secretion of this placental lactogen in the maternal compartment is not fully understood. Some studies in the ewe (Martal and Lacroix, 1978 ; Lowe et al., 1979) and the goat (Hayden et al., 1980) suggest an interaction between the secretion of PRL and OCS. For this reason, we examined the possibility of a seasonal influence or of a variation in daylength on the 
secretion of PRL, OCS and LH during pregnancy in sheep. To do this, we observed the blood levels of these hormones in animals inseminated at three different periods of the year, taking into account the number of their fetuses.

\section{Material and methods}

Animals. - The lle-de-France ewes used in this study were artificially inseminated at induced oestrus with the sperm of rams of the same breed (Thimonier et al., 1975). They were kept in a barn under natural light and temperature throughout gestation and were fed in a group once daily with the same ration of dehydrated alfalfa (500 g/ewe) and corn $(400 \mathrm{~g} / \mathrm{ewe})$, supplemented with a commercial ration (Sanders, France ; Brebis laitières) during the last month of gestation.

Experimental groups. - Three groups were constituted according to the date of insemination ; 15 September, group I ; 10 November, group II ; 16 March, group III (table 1). In each group, $5 \mathrm{ml}$ of peripheral venous blood were taken in heparinized tubes from the third month of gestation until parturition. The blood, sampled at $10.00 \mathrm{~h}$ for two consecutive days approximately every 10 days, was centrifuged and the plasma stored at $-20^{\circ} \mathrm{C}$ until assayed. The timing of insemination of the groups and the sampling dates were such that group I was sampled around the winter solstice, group II during spring when the daylength was increasing, and group III around the summer solstice. Figure 1 shows the photoperiodic variation received by each experimental group. The ewes of each group gave birth to live lambs at parturition, which was induced (Bosc, 1972) a few days after the last sampling. Table 1 presents details on the litter size and birth weight of each group. In group III, the mean total weight of triplets was not significantly different from that of twins in groups I and II.

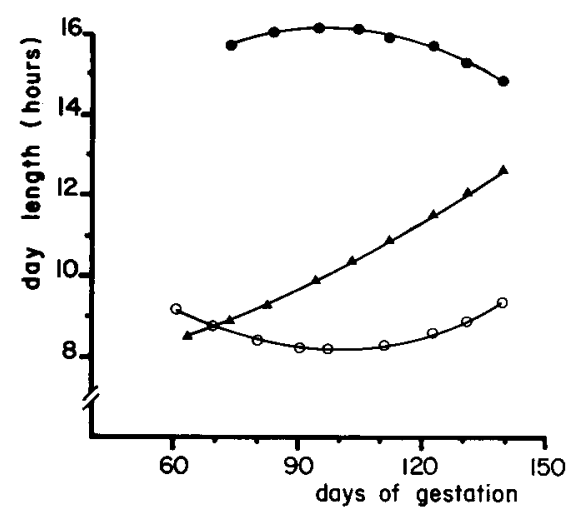

FIG. 1. - Variations of daylength in the three experimental groups. (Points represent times of sampling during gestation.)

○ـ G I sampling from november to jonuary

— G II sampling from january to march

- GIII sompling from may to august 
TABLE 1

Number of ewes and birth weight of lambs $(m+s d)$ according to litter size in the three experimental groups

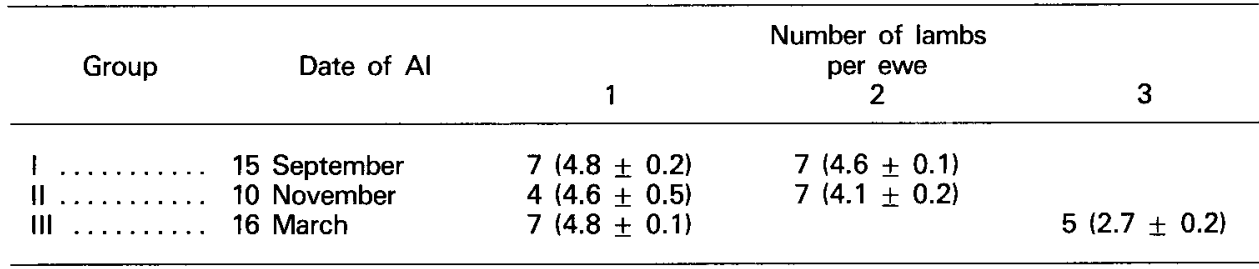

Assays and analysis. - Determinations of LH and PRL were done by radioimmunoassays, as previously described. LH (Pelletier et al., 1968, 1982) sensitivity was $0.15 \mathrm{ng} / \mathrm{ml}$, and that of PRL (Kann, 1971) was $0.3 \mathrm{ng} / \mathrm{ml}$. OCS was measured by a radioreceptor assay (Djiane and Kann, 1975) with the difference that the lactogenic activity of the plasma was determined without measuring the levels of prolactin (Smith and Djiane, 1982); human growth hormone was used as a tracer and the results were expressed in $\mathrm{ng} \mathrm{hGH}$ equivalents. Assay sensitivity was $40 \mathrm{ng} / \mathrm{ml}$.

The levels of these hormones were analyzed from the mean values for the two consecutive days of sampling. The mean daily levels of each hormone were computed for each ewe from the area under the curve which plotted the hormonal levels against the sampling period. These $\mathrm{LH}$ values were analyzed according to the parametric test of Fisher (Snedecor and Cochran, 1957). The PRL and OCS values were treated according to the non-parametric tests of Mann-Whitney and of Kruskall and Wallis (Siegel, 1956 ; Dagnelie, 1970). In addition, the concordance coefficient (W) of Kendall (Siegel, 1956) was computed for PRL and OCS to express the degree of homogeneity of the pattern of hormonal levels throughout the observation period for each group.

\section{Results}

The pattern of plasma PRL levels is presented on fig. 2. The PRL levels in all groups were relatively stable during the third month of gestation, but they were higher $(P<0.01)$ in group III than in the other two groups (fig. 2). After this, the PRL levels increased more or less until parturition, according to the group. They were therefore higher in group III than in group I (fig. $2 ; \mathrm{P}<0.01$ ) during the last month of gestation.

These trends marked large individual variations (fig. 2), as indicated by the range of values for the concordance coefficient of Kendall (table 2). But in most animals, and particularly in those of group II which were under increasing daylength, these $W$ values (table 2 ) indicated a significant relationship between the PRL levels and the stages of pregnancy. Comparisons of daily plasma PRL levels in each group did not show a difference between animals with one fetus 


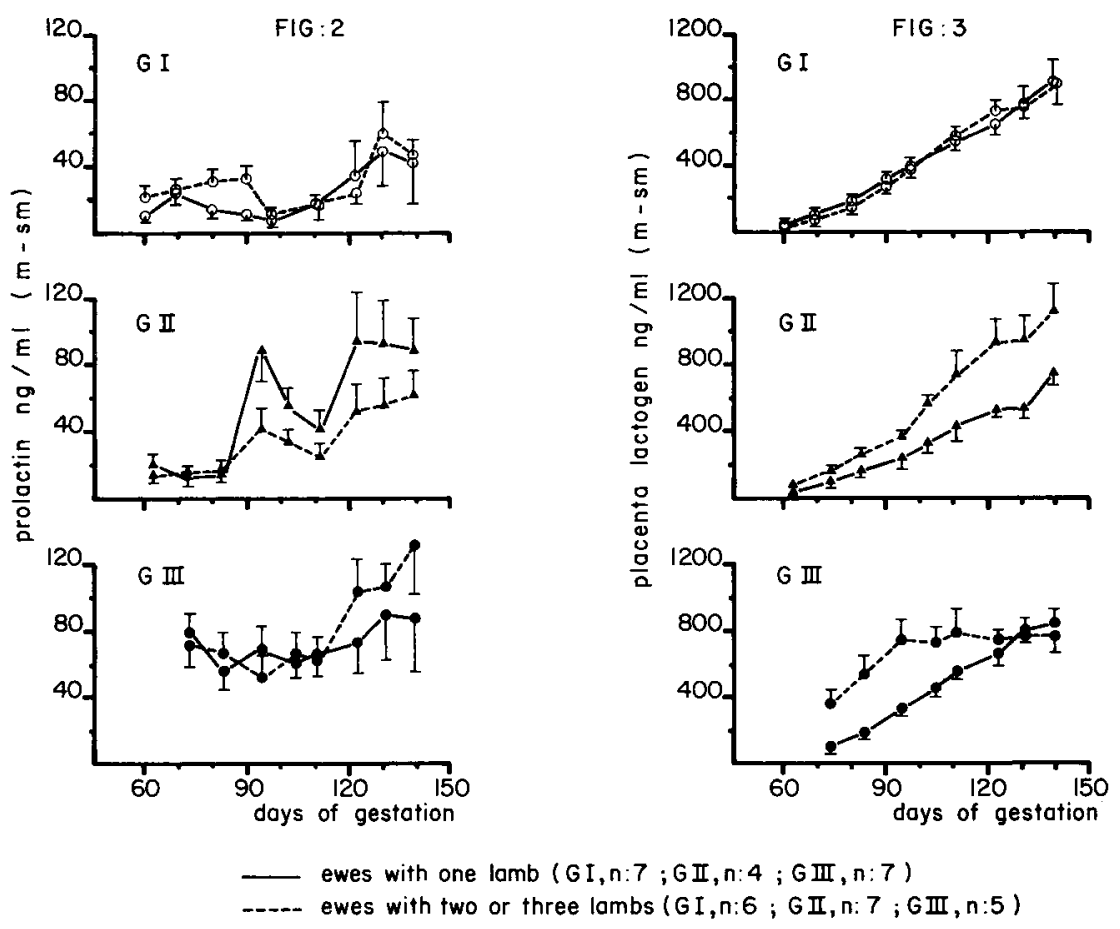

FIG. 2. - Average blood prolactin levels.

FIG. 3. - Average blood placental lactogen (OCS) in pregnant ewes during

and those with several fetuses (table $2 ; P>0.05$ ), but there was a significant overall difference between groups (table $2 ; P<0.05$ ).

The levels of OCS shown on figure 3 increased progressively during gestation in ewes which had one fetus. The high value of more than 0.9 for Kendall's concordance coefficient indicates that individual animals differed only slightly from this pattern (table 2). An identical pattern was observed in those with two fetuses (table 2), but ewes with triplets (group III) were different from the others; their OCS levels increased until days $94-95$ of gestation and then remained at a plateau of about $750 \mathrm{ng} / \mathrm{ml}$ until parturition (fig. 3). In groups II and III, the OCS levels depended on the number of fetuses (fig. 3 ; table 2 ; $P<0,05$ ) ; this was not the case in group I (fig. 3 ; table $2 ; P>0.05$ ). For animals having one fetus, group II had lower mean daily levels of OCS than groups I and III (table $2 ; P<0.05$ ). For animals which had 2 or 3 fetuses, the levels of OCS were significantly lower $(P<0.05)$ in group I than in groups II and III (table 2).

The pattern of LH levels, presented on fig. 4, remained around $0.5-0.6 \mathrm{ng} / \mathrm{ml}$ in the three groups throughout the second half of gestation. It was not affected by the number of fetuses (table 2) or the time of the year, 


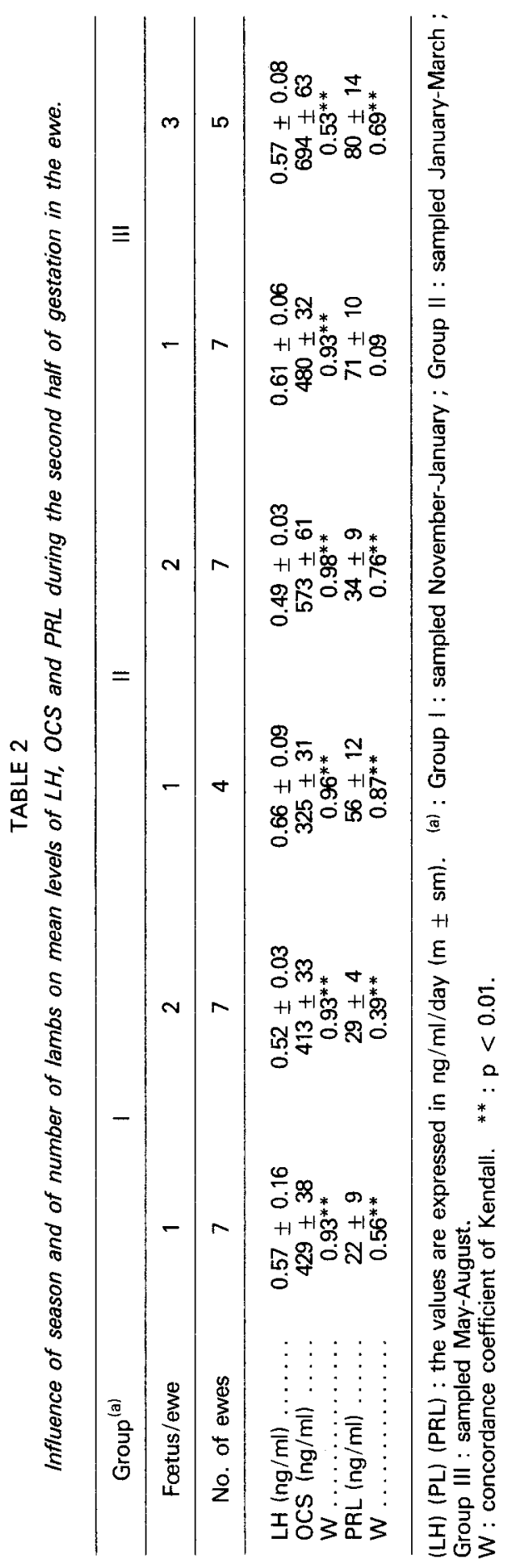


although animals pregnant in summer had slightly higher levels of LH than those pregnant during the winter (fig. 4).

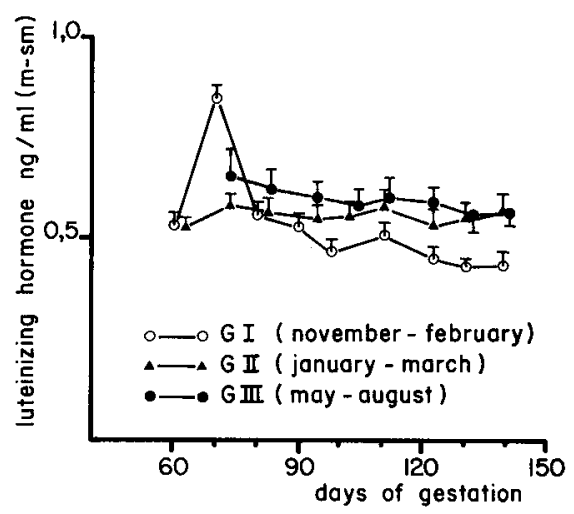

FIG. 4. - Average blood $\mathrm{LH}$ levels in prenant ewes during the last three months of gestation at three different periods of the year.

\section{Discussion}

This experiment confirms the earlier results of Kann and Denamur (1974) showing that plasma PRL levels increase in maternal blood during late gestation in sheep. It also shows that maternal PRL levels are influenced during the second half of gestation by the season and, therefore, probably by daylength. This was observed in all three groups but is particularly highlighted by groups I and III. Thus, average blood PRL levels were three times less in the animals pregnant around the winter solstice (group I) than in those pregnant during the summer solstice (group III). In both these groups, differences in PRL concentrations were observed during the third month of gestation as well as during late gestation, a time when there are usually high levels of plasma PRL (Kann and Denamur, 1974). The results observed in animals of group II, which were pregnant under increasing daylength, are similar to those of the other two groups at the same stages of gestation and daylength. From observations at early gestation (Rhind et al., 1978) and from the results of this experiment, it appears that blood PRL concentrations in the ewe during pregnancy are influenced by the season. However, the relationship between the variation in daylength and PRL seems to be less marked in the pregnant than in the nonpregnant (Thimonier et al., 1978) or castrated (Kann, 1980) ewe or in the ram (Ravault, 1976). Plasma PRL in sheep is thus influenced by the season and stage of gestation but the interaction between these factors is complex. The placental lactogenic hormone (Martal and Djiane, 1977; Martal et al., 1977 ; Reddy and Watkins, 1978) is usually secreted in both the fetal and the maternal compartments (Chan et al., 1978 ; Gluckman et al., 1979; Lowe et al., 1979 ; Taylor et al., 1980). Our study, which was limited to the maternal side, shows an increase of OCS concentrations in most cases as gestation progresses. This pattern was observed whatever the variations of the PRL levels. Thus, in our 
conditions, no apparent interaction was noted between PRL and OCS in maternal blood. This is in agreement with the results of Martal and Lacroix (1978) but not with those of Lowe et al. (1979), which were both obtained after administration of an antagonist of PRL secretion. Lowe et al. (1979) noted an alteration of placental OCS cells after the treatment. In fact, PRL is known to have a marked circadian rhythm of secretion in the ram (Ravault et al., 1980) or the non-pregnant ewe (Walton et al., 1980), and levels of OCS may show wide hourly fluctuation (Taylor et al., 1980). In order to clarify this problem, it would be interesting to observe PRL and OCS concentrations on a circadian basis at different stages of gestation.

In this study, OCS concentrations show some variations in the three experimental groups. The number of fetuses influenced the OCS levels in two groups (groups II and III), the ewes bearing several fetuses having more OCS than those having a single lamb. We do not know why this effect of litter size on OCS levels (Thimonier et al., 1977 ; Gluckman et al., 1979) was not found in group I. It is thus difficult to compare the OCS patterns of multiple pregnancies in the three experimental groups. However, in this experiment, the animals with single pregnancies showed the same patterns of OCS concentrations in winter (group I) and summer (group III), in spite of the observed difference in the PRL levels. This suggests that there is no seasonal effect on OCS maternal blood levels under our conditions. This lack of either a seasonal effect or a marked circadian rhythm (Chan et al., 1978; Taylor et al., 1980) indicates that, in contrast to prolactin secretion into the maternal blood, that of OCS is not photodependent.

During pregnancy, concentrations of LH characterize maternal hypophyseal secretion since the placenta is impermeable to this hormone (Foster et al., 1972). These levels did not vary significantly with the number of fetuses and therefore presumably with the levels of progesterone (Stabenfeldt, 1974), confirming earlier observations (Shevah et al., 1975). In the present study, the LH concentrations remained low in the maternal blood throughout the second half of gestation in the ewe, as they do at the beginning of gestation (Pratt et al., 1977) or in late gestation (O'Reilly and Dziuk, 1973 ; Shevah et al., 1975). Since the LH levels did not vary among the groups, the photoperiod seems to have no effect on them. LH is known to have a pulsatile secretion in the ram (Bolt, 1971) or the non-pregnant ewe (Akbar et al., 1974 ; Terqui et al., 1980). However, pulses have a diurnal rhythm whose frequencies are light-dependent since they are maximal in June and minimal in December (Terqui et al., 1980 ; Ravault et al., 1980). Because we sampled only once daily, our technique may have masked an effect of daylength, but even so the LH levels were very stable in the three experimental groups.

Reçu en juillet 1981.

Accepté en décembre 1981.

Résumé. Les concentrations plasmatiques moyennes de Prolactine (PRL) d'hormone placentaire lactogène (OCS) et d'hormone luteinisante (LH) ont été suivies dans 3 lots de brebis gravides à 3 saisons différentes. Les prélèvements ont été réalisés tous les dix jours 
environ, 2 jours consécutifs, à partir du $60^{\mathrm{e}}$ jour de la gestation jusqu'à la parturition ; dans le lot $I$ les prélèvements ont été faits au moment du solstice d'hiver (IA en septembre), dans le lot II, ils ont été faits au cours du printemps (IA en novembre) et dans le lot III, au moment du solstice d'été (IA en mars). Les résultats indiquent que les taux de PRL, dont l'évolution dépend du déroulement de la gestation, sont significativement modifiés par la saison. Les animaux du lot I ont eu respectivement des taux moyens 3 fois et 2 fois inférieurs par rapport à ceux du lot III, au $3^{e}$ et au $5^{e}$ mois de la gestation. Les taux de OCS, dont l'évolution est fortement liée au stade de gestation, n'ont pas été modifiés, dans nos conditions, par la saison. Les concentrations de $\mathrm{LH}$, de l'ordre de 0.5 $0.6 \mathrm{ng} / \mathrm{ml}$ dans les 3 lots n'ont pas varié au cours des 3 derniers mois de la gestation.

\section{Références}

AKBAR A. M., NETT T. M., NISWENDER D. G., 1974. Metabolic clearance and secretion rates of gonadotropins at different stages of the estrous cycle in ewes. Endocrinology, 94. 1318-1324.

BOLT D. J., 1971. Changes in the concentration of $\mathrm{LH}$ in plasma of rams following administration of œstradiol, progesterone or testosterone. J. Reprod. Fert., 24, 435-438.

BOSC M. J., 1972. The induction and synchronisation of lambing with the aid of dexamethasone. J. Reprod. Fert., 28, 347-357.

CHAN J. S. D., ROBERTSON H. A., FRIESEN H. G., 1978 . Maternal and fetal concentrations of ovine placental lactogen measured by radioimmunoassay. Endocrinology, 102, 1606-1615.

DAGNELIE P., 1970. Théorie et méthodes statistiques. Vol, 2, J. Duculot S.A., Gembloux.

DJIANE J., KANN G., 1975. Mise en évidence de l'activité lactogène et mesure dans le sérum de l'activité prolactinique du placenta chez la brebis au cours de la gestation. C. R. Acad. Sci. Paris, Sér. D, 280, 2785-2788.

FOSTER D. L., KARSCH F. J., NALBANDOV A. V., 1972. Regulation of luteinizing hormone (LH) in the fetal and neonatal lamb. II. Study of placental transfer of $\mathrm{LH}$ in the Sheep. Endocrinology, 90, 589-592.

GLUCKMAN P. D., KAPLAN S. L., RUDOLPH A. M., GRUMBACH M. M., 1979. Hormone ontogeny in the ovine fetus. II. Ovine chorionic somatomammotrophin in mid and late gestation in the fetal and maternal circulations. Endocrinology, 104, 1828-1833.

HAYDEN T. J., THOMAS C. R., SMITH S. V., FORSYTH I. A., 1980. Placental lactogen in the goat in relation to stage of gestation, number of fetuses, metabolites, progesterone and time of day. J. Endocr., 86, 279-280.

KANN G., 1971. Dosage radioimmunologique de la prolactine plasmatique chez les ovins. $C$. $R$. Acad. Sci. Paris, Sér. D, 272, 2934-2937.

KANN G., 1980. Prolactine chez la brebis adulte. Sécrétion et rôle. Th. Dr. Sci. nat., Univ. Paris VI, pp. 124.

KANN G., DENAMUR R., 1974. Possible role of prolactin during the œstrous cycle and gestation in the ewe. J. Reprod. Fert., 39, 473-483.

KELLY P. A., ROBERTSON H. A., FRIESEN H. G., 1974. Temporal pattern of placental lactogen and progesterone secretion in sheep. Nature, 242, 435-437.

LOWE K. C., BECK N. F., MCNAUGHTON D. C., GLUCKMAN P. D., KAPLAN S. L., GRUMBACK M. M., NATHANEILSZ P. W., 1979. Effect of long-term bromocriptine infusion on plasma prolactin and ovine chorionic somatomammotropin in the pregnant ewe and fetal sheep. Am. J. Obstet. Gynecol., 135, 773-777.

MARTAL J., DJIANE J., 1977 . The production of chorionic somatomammotrophin in sheep. $J$. Reprod. Fert., 49, 285-289.

MARTAL J., DJIANE J., DUBOIS M. P., 1977. Immunofluorescent localization of ovine placental lactogen. Cell. Tiss. Res., 184, 427-433.

MARTAL J., LACROIX M. C., 1978. Production of chorionic somatomammotropin (oCS), fetal growth and growth of the placenta and the corpus luteum in ewes treated with 2-bromo $\alpha$-ergocryptin. Endocrinology, 103, 193-199.

O'REILLY P. J., DZIUK P. J., 1973. Change in the level of LH in the sera and pituitaries of ovariectomized and intact ewes at parturition. Endocrinology, 92, 1575-1578. 
PELLETIER J., KANN G., DOLAIS J., ROSSELIN G., 1968. Dosage radioimmunologique de l'hormone luteinisante plasmatique de mouton. Mise au point de la technique de dosage. C. R. Acad. Sci. Paris, Sér. D, 266, 2291-2294.

PELLETIER J., ORTAVANT R., 1970. Influence du photoperiodisme sur l'activité sexuelle hypophysaire et hypothalamique du Bélier lle-de-France. In Coll. int. C.N.R.S. $\mathrm{n}^{\circ} 172,483-495$. BENOIT J., ASSENMACHER I., La photoregulation de la reproduction chez les oiseaux et les mammifères, C.N.R.S., Paris.

PELLETIER J., GARNIER D. H., de REVIERS M. M., TEROUI M., ORTAVANT R., 1982. Seasonal variation in $\mathrm{LH}$ and testosterone release in two breeds of rams. J. Reprod. Fert. (in press).

PRATT B. R., BUTCHER R. L., INSKEEP E. K., 1977. Antiluteoiytic effecti of the conceptus and of $\mathrm{PGE}_{2}$ in ewes. J. anim. Sci., 46, 784-791.

RAVAULT J.P., 1976. Prolactin in the ram : seasonal variations in the concentrations of blood from birth until three years old. Acta endocrinol., 63, 720-725.

RAVAulT J. P., BLANC M., ORTAVANT R., PELLETIER J., de REVIERS M. M., 1980. Variations circadiennes et circaannuelles de la sécrétion de prolactine (PRL), LH et FSH chez les animaux domestiques mâles, 115-128. In ORTAVANT R., REINBERG.A., Rythmes et reproduction. Masson, Paris.

REDDY S., WATKINS W. B., 1978. Immunofluorescence localization of ovine placental lactogen. J. Reprod. Fert., 52, 174-174.

RHIND S. M., CHESWORTH J. M., ROBISON J. J., 1978. A seasonal difference in ovine peripheral plasma prolactin and progesterone concentrations in early pregnancy and in the relationship between the two hormones. J. Reprod. Fert., 52, 79-81.

SHEVAH Y., BLACK W. J. M., CARR W. R., LAND R. B., 1975. The effects of nutrition on the reproductive performance of Finn $\times$ Dorset ewes. J. Reprod. Fert., 45, 283-288.

SIEGEL S., 1956. Non-parametric statistics for the behavioural sciences. McGrawhill Book Company, McKogakusha Company Ltd.

SMITH M. C., DJIANE J., 1982. An improved method of measuring placental lactogen by radioreceptor assay : application to the determination of plasma concentrations of placental lactogen in the pregnant goat. $J$. Endocr. (in press).

SNEDECOR G. W., COCHRAN W. G., 1957. Statistical methods. 6th ed. (The lowa State Union Press) Ames Lowa. U.S.A.

STABENFELDT G. H., 1974. The role of progesterone in parturition : premature, normal, prolonged gestation, 97-122. In M. J. BOSC, E. PALMER, Cl. SUREAU, Avortement et parturition provoqués. Masson, Paris.

TAYLOR M. J., JENKIN G., ROBINSON J. J., THORBURN G. D., FRIESEN M., CHAN J. S. D., 1980. Concentrations of placental lactogen in chronically catheterized ewes and fetuses in late pregnancy. J. Endocr., 85, 27-34.

TERQUI M., GARNIER D. H., de REVIERS M. M., HUET S., PELLETIER J., 1980. La structure chronologique du dialogue entre l'hypophyse et la gonade chez les mammifères domestiques, 59-72. In R. ORTAVANT, A. REINBERG, Rythmes et reproduction. Masson, Paris.

THIMONIER J., MAULÉON P., 1969. Variations saisonnières du comportement d'œestrus et des activités ovariennes et hypophysaires chez les ovins. Ann. Biol. anim. Bioch. Biophys., 9, 233-250.

THIMONIER J., COGNIÉ Y., CORNU C., SCHNEBERGER J., VERNUSSE G., 1975. Intensive lamb production. Ann. Biol. anim. Bioch. Biophys., 15, 365-367.

THIMONIER J., BOSC M., DJIANE J., MARTAL J., TERQUI M., 1977. Hormonal diagnosis of pregnancy and number of fetuses in sheep and goats, 79-88. In Management of reproduction in sheep and goat Symp., ed. Sheep Ind. Devpt. Program-Am. soc. anim. Sc-Am. Assoc. Sheep Goat Practitionners, Madison.

THIMONIER J., RAVAULT J. P., ORTAVANT R., 1978. Plasma prolactin variations and cyclic ovarian activity in ewes submitted to different light regimens. Ann. Biol. anim. Bioch. Biophys., 18, 1229-1235.

WALTON J. S., EVINS J. D., FITZGERALD B. P., CUNNINGHAM F. S., 1980. Abrupt decrease in daylength and short-term changes in the plasma concentrations of $\mathrm{FSH}, \mathrm{LH}$ and prolactin in anoestrus ewes. J. Reprod. Fert., 59, 163-171. 